\title{
Environmental influence on the euglenoid species diversity and their abundance in Museum Lake, Thiruvananthapuram, India
}

\author{
Anila P. Ajayan ${ }^{1,4, *}$, Jan W. Rijstenbil ${ }^{2}$ and K. G. Ajit Kumar ${ }^{3}$ \\ ${ }^{1}$ Environmental Biology Division, Department of Botany, Mahatma Gandhi College, Thiruvananthapuram 695 004, India \\ ${ }^{2}$ AE3 Consultancy, Fuchsialaan 8, 4401HV Yerseke, The Netherlands \\ ${ }^{3}$ Kerala State Biodiversity Board, Thiruvananthapuram 695 011, India \\ ${ }^{4}$ Present address: State Key Laboratory of Freshwater Ecology and Biotechnology, Freshwater Algal Ecology Division, Institute of Hydrobiology, \\ Chinese Academy of Sciences, Wuhan 430072, China
}

Twenty-three species belonging to the class Euglenophyceae were recorded from the Museum Lake, Thiruvananthapuram, India. A canonical correspondence analysis (CCA) between environmental variables and the dominant euglenophytes indicated interaction with certain physical and chemical parameters, in particular rainfall, electrical conductivity and phosphate versus their distribution in the Museum Lake. The dominant species were Euglena deses, Trachelomonas hispida and Trachelomonas volvocina. The CCA results indicate interaction between a variety of environmental parameters and species abundance. A closer examination suggests some external factor (e.g. evaporation) affecting water quality rather than the environment changing the algal biomass. With low rainfall the phosphate concentration increased from 1.5 to $6.9 \mathrm{mg} \mathrm{P} / \mathrm{l}$ (likely as a result of anoxic conditions in the muddy bottom) and simultaneously nitrate was (partly) taken up by these dominant algae, as a result of which $N$ : $P$ ratios decreased from 4.5 to 0.7 . The present study shows that the dominant euglenoid species co-occur in relatively hard water with high phosphorus concentration, and can be considered as useful bio-indicators in assessing the health and extent of deterioration of a lake ecosystem.

Keywords: Canonical correspondence analysis, environmental variables, euglenoid species, lake ecosystem.

EUGLENOPHYTES are microscopic, planktonic microorganisms that contribute to the primary production of an aquatic ecosystem. These groups of phytoplankton are studied mainly for their ecological importance as indicators of water pollution. Most of them are mixotrophic ${ }^{1}$, i.e. switching between photosynthesis and carbon utilization (dissolved and particulate). Hence these freshwater flagellates are considered as good indicators of organic pollution $^{2,3}$. In India various taxonomic studies have been carried out on the diversity of euglenoids ${ }^{4-15}$. However, only a few of them deal with their relationship to pollu-

\footnotetext{
*For correspondence. (e-mail: anila.dehradun@gmail.com)
}

tion levels ${ }^{16-20}$. The present work aims at highlighting the abundance and distribution of the (dominant) euglenoids in a small lake-Museum Lake, Thiruvananthapuram, Kerala, India, that receives inputs of organic matter (bat faeces, litter) from its surroundings. The relationships between euglenoid abundance in the lake and a number of environmental variables are studied throughout the seasons. The question is whether the euglenoids present are suitable as indicators of (organic) pollution.

\section{Materials and methods}

The Thiruvananthapuram Museum and Zoo is one of the oldest of its kind in India located at the heart of the city $\left(08^{\circ} 30^{\prime} \mathrm{N}, 076^{\circ} 57^{\prime} \mathrm{E}\right)$. The present study was carried out in the small, expansive Museum Lake inside the zoo, which extends over an area of ca. $9000 \mathrm{~m}^{2}$ and maximum depth of $6 \mathrm{~m}$. Figure 1 shows the location map of the study area. It is a natural waterbody that maintains its water level even in the scorching summers. The waterbody is oriented in a north-south direction. The southern part is completely covered by floating macrophytes such as Pistia sp. and Lemna sp. A large bat population inhabiting the surrounding trees, as well as indigenous and exotic bird species in the trees of a small island in the lake, enrich it (and its bottom) with their faeces. In order to study seasonal variations in euglenoid cell numbers with variations of environmental parameters, samples were collected for two consecutive years. Monthly data were divided into three seasons (Box 1).

\section{Phytoplankton analyses}

Water samples were collected from the lake in clean plastic bottles. Samples were taken at random at mid-depth in the water column and pooled. Samples were preserved by adding $1 \mathrm{ml} / 1$ 4\% formalin solution. A Sedgwick Rafter cell was used to count the micro-algae in concentrated samples; species density/abundance was given in cells $/ \mathrm{ml}$. For identification, photomicrographs of the algae were 


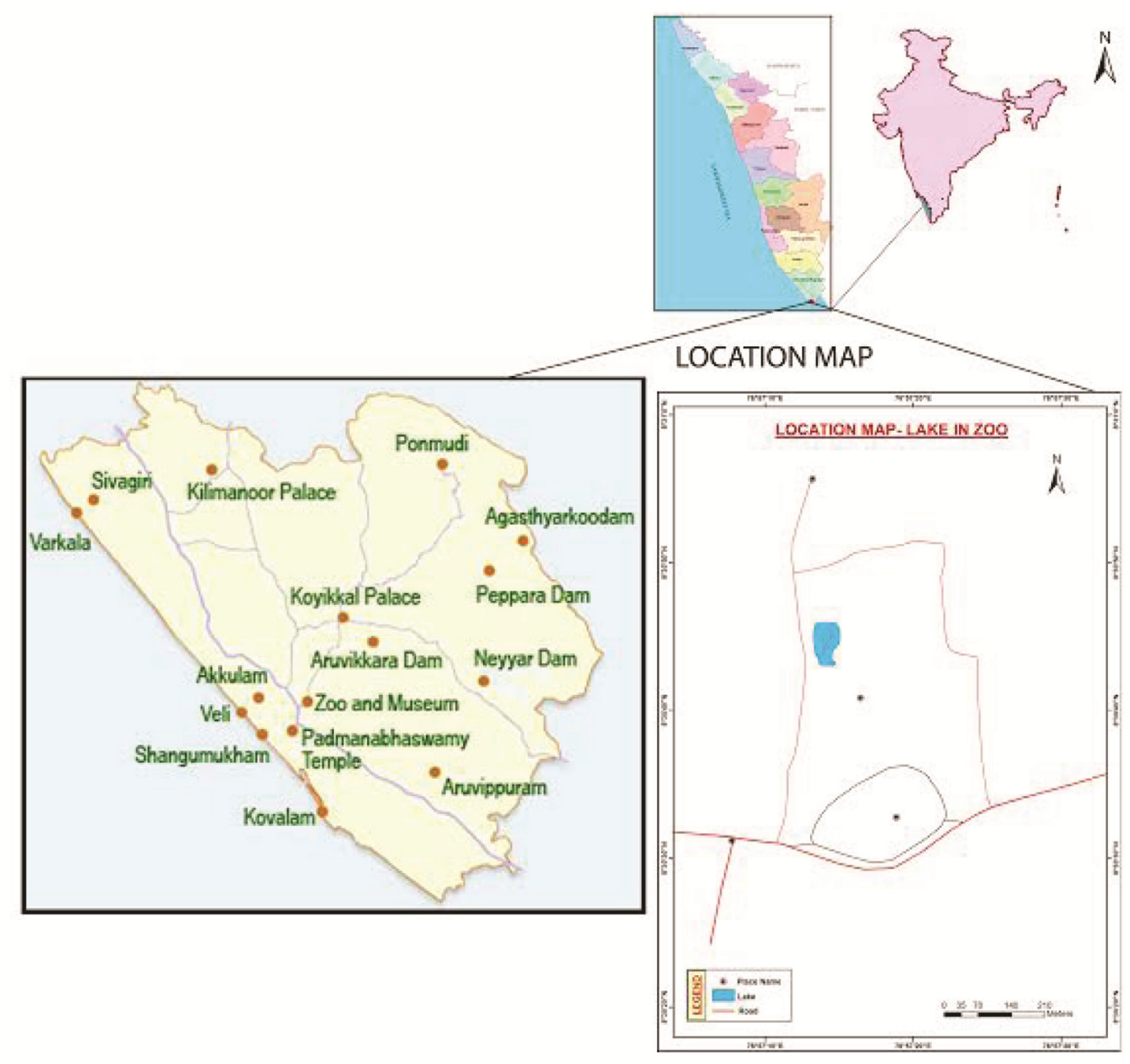

Figure 1. Location map of the Museum Lake, Thiruvananthapuram, India.

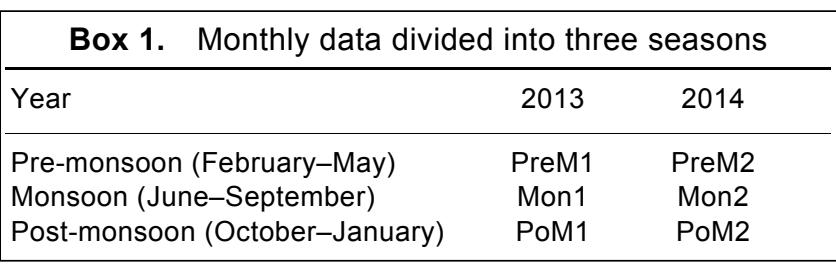

taken using a camera attached to compound microscope (Leica DM500). The taxonomic works of Philipose ${ }^{8-10}$, Woloski and Hindák ${ }^{21}$, Ciugulea and Triemer ${ }^{22}$ and Triemer and Zakrys ${ }^{23}$ as well as on-line websites like Phycokey and Algaebase were consulted for identification of the euglenoids.

\section{Environmental parameters}

With a portable $\mathrm{pH}$ meter and a centigrade thermometer, the in situ $\mathrm{pH}$ and water temperature $\left({ }^{\circ} \mathrm{C}\right)$ were measured. Rainfall data (mm/season) was obtained from India Meteorological Department, Thiruvananthapuram. Electrical conductivity $(\mathrm{EC}, \mu \mathrm{S} / \mathrm{cm})$ and total dissolved solids
(TDS, ppm) were measured with a digital TDS/conductivity meter (MK-509). Dissolved oxygen concentration (DO), biological oxygen demand (BOD), chemical oxygen demand (COD), total alkalinity (TA), total hardness $(\mathrm{TH})$, magnesium $\left(\mathrm{Mg}^{2+}\right)$, calcium $\left(\mathrm{Ca}^{2+}\right)$, sodium $\left(\mathrm{Na}^{+}\right)$, potassium $\left(\mathrm{K}^{+}\right)$, nitrate $\left(\mathrm{NO}_{3}^{-}-\mathrm{N}\right)$, nitrite $\left(\mathrm{NO}_{2}^{-}-\mathrm{N}\right)$, soluble reactive phosphate $\left(\mathrm{PO}_{4}-\mathrm{P}\right)$ and silicate $(\mathrm{Si})$ were analysed using standard methods ${ }^{24-26}$.

\section{Statistics}

The euglenoid composition and abundance in relation to environmental parameters (physical and chemical data) were derived from canonical correspondence analysis (CCA) using Paleontological Statistics Version 3.10 (PAST).

\section{Results and discussion}

Tables 1 and 2 give the mean values plus their variations (mean \pm SD) in hydrographic parameters for the study 
Table 1. Mean and variation (mean \pm SD) of hydrological parameters in the Museum Lake, Thiruvananthapuram for year 1 (2013-14)

\begin{tabular}{|c|c|c|c|c|}
\hline Parameters & Units & Pre-monsoon (PreM1) & Monsoon (Mon1) & Post-monsoon (PoM1) \\
\hline Rainfall & $\mathrm{mm} / \mathrm{season}$ & 65 & 141 & 243 \\
\hline Water temperature & ${ }^{\circ} \mathrm{C}$ & $23.7 \pm 1.5$ & $23.25 \pm 0.5$ & $23 \pm 0.82$ \\
\hline $\mathrm{pH}$ & - & $6.9 \pm 0.42$ & $6.8 \pm 0.34$ & $6.9 \pm 0.52$ \\
\hline Dissolved oxygen (DO) & $\mathrm{mg} \mathrm{O}_{2} / 1$ & $11.29 \pm 10.98$ & $8.28 \pm 4.02$ & $8.08 \pm 5.11$ \\
\hline Biological oxygen demand (BOD) & $\mathrm{mg} \mathrm{O}_{2} / 1$ & $10.07 \pm 10.11$ & $8.29 \pm 4.29$ & $6.00 \pm 5.45$ \\
\hline Chemical oxygen demand (COD) & $\mathrm{mg} / 1$ & $43.60 \pm 16.30$ & $30.08 \pm 9.67$ & $43.35 \pm 10.35$ \\
\hline Total alkalinity & $\mathrm{mg} \mathrm{CaCO} 3 / 1$ & $21.56 \pm 2.99$ & $16.63 \pm 3.38$ & $17.35 \pm 1.27$ \\
\hline Nitrate-nitrogen & mg N/1 & $1.73 \pm 1.55$ & $3.99 \pm 1.54$ & $2.60 \pm 0.07$ \\
\hline Nitrite-nitrogen & $\mathrm{mg} \mathrm{N} / 1$ & $0.39 \pm 0.30$ & $0.90 \pm 0.21$ & $0.22 \pm 0.18$ \\
\hline Calcium & $\mathrm{mg} \mathrm{Ca} / 1$ & $13.4 \pm 5.95$ & $18.65 \pm 3.59$ & $17.23 \pm 3.05$ \\
\hline Total hardness & $\mathrm{mg} \mathrm{CaCO} 3 / 1$ & $69.44 \pm 26.76$ & $62.59 \pm 8.22$ & $63.25 \pm 30.54$ \\
\hline Magnesium & $\mathrm{mg} \mathrm{Mg} / 1$ & $13.30 \pm 5.30$ & $14.11 \pm 5.88$ & $11.03 \pm 6.77$ \\
\hline Phosphate & $\mathrm{mg} \mathrm{P} / 1$ & $6.87 \pm 3.22$ & $3.46 \pm 2.12$ & $1.43 \pm 0.91$ \\
\hline Silicate & $\mathrm{mg} \mathrm{Si} / 1$ & $5.35 \pm 5.19$ & $8.06 \pm 3.35$ & $9.72 \pm 3.00$ \\
\hline Sodium & $\mathrm{mg} \mathrm{Na} / 1$ & $4.88 \pm 2.17$ & $4.94 \pm 1.22$ & $5.13 \pm 1.05$ \\
\hline Potassium & $\mathrm{mg} \mathrm{K} / 1$ & $6.16 \pm 4.48$ & $12.24 \pm 10.81$ & $11.68 \pm 11.48$ \\
\hline Total dissolved solids (TDS) & ppm & $76.30 \pm 7.35$ & $77.72 \pm 3.47$ & $76.41 \pm 10.46$ \\
\hline Conductivity & $\mu \mathrm{S} / \mathrm{cm}$ & $156.20 \pm 6.28$ & $147.10 \pm 8.16$ & $153.88 \pm 6.05$ \\
\hline
\end{tabular}

Table 2. Mean and variation (mean \pm SD) of hydrological parameters in the Museum Lake for year 2 (2014-15)

\begin{tabular}{|c|c|c|c|c|}
\hline Parameters & Units & Pre-monsoon (PreM2) & Monsoon (Mon2) & Post-monsoon (PoM2) \\
\hline Rainfall & $\mathrm{mm} / \mathrm{season}$ & 268 & 101 & 140 \\
\hline Water temperature & ${ }^{\circ} \mathrm{C}$ & $24 \pm 0.96$ & $23 \pm 0.82$ & $23 \pm 0.82$ \\
\hline $\mathrm{pH}$ & - & $7.05 \pm 0.58$ & $6.8 \pm 0.32$ & $6.6 \pm 0.2$ \\
\hline DO & $\mathrm{mg} \mathrm{O}_{2} / 1$ & $6.10 \pm 3.33$ & $7.2 \pm 3.71$ & $4.88 \pm 2.06$ \\
\hline BOD & $\mathrm{mg} \mathrm{O}_{2} / 1$ & $5.31 \pm 3.50$ & $6.79 \pm 5.1$ & $3.48 \pm 0.66$ \\
\hline COD & $\mathrm{mg} / 1$ & $38.47 \pm 15.32$ & $36.09 \pm 10.44$ & $45.87 \pm 6.20$ \\
\hline Nitrate-nitrogen & $\mathrm{mg} \mathrm{N} / 1$ & $4.10 \pm 4.70$ & $3.03 \pm 0.77$ & $2.88 \pm 2.37$ \\
\hline Nitrite-nitrogen & $\mathrm{mg} \mathrm{N} / 1$ & $0.38 \pm 0.36$ & $0.58 \pm 0.24$ & $0.14 \pm 0.02$ \\
\hline Calcium & $\mathrm{mg} \mathrm{Ca} / 1$ & $13.38 \pm 4.61$ & $19.54 \pm 5.78$ & $13.79 \pm 1.91$ \\
\hline Total hardness & $\mathrm{mg} \mathrm{CaCO}_{3} / 1$ & $30.48 \pm 12.59$ & $62.41 \pm 12.69$ & $61.23 \pm 0.54$ \\
\hline Magnesium & $\mathrm{mg} \mathrm{Mg} / 1$ & $4.52 \pm 3.62$ & $10.45 \pm 4.45$ & $11.32 \pm 3.59$ \\
\hline Phosphate & $\mathrm{mg} \mathrm{P} / 1$ & $2.79 \pm 1.13$ & $3.67 \pm 1.91$ & $1.66 \pm 0.53$ \\
\hline Silicate & $\mathrm{mg} \mathrm{Si} / 1$ & $8.31 \pm 5.43$ & $6.5 \pm 2.55$ & $6.27 \pm 2.75$ \\
\hline Potassium & $\mathrm{mg} \mathrm{K} / 1$ & $4.82 \pm 5.43$ & $3.56 \pm 0.85$ & $13.32 \pm 9.60$ \\
\hline TDS & ppm & $75.73 \pm 7.03$ & $72.01 \pm 6.65$ & $71.55 \pm 3.56$ \\
\hline Conductivity & $\mu \mathrm{S} / \mathrm{cm}$ & $160.68 \pm 13.12$ & $137.67 \pm 8.35$ & $144.79 \pm 16.43$ \\
\hline
\end{tabular}

period. These were all used as independent variables in the CCA.

Twenty-three Euglenophyceae species (of the genera Euglena, Lepocinclis, Phacus and Trachelomonas) were recorded from the Museum Lake (Table 3), among which Euglenaria clepsydroides was newly recorded in India ${ }^{3}$. Table 4 gives the average cell number in the two-year sampling period; Euglena deses, Trachelomonas volvoci$n a$ and Trachelomonas hispida were the dominant species. Euglenoid cell numbers were highest during PreM1 and lowest during Mon2. Figure 2 gives the seasonal development of the three dominant euglenoids. E. deses showed a decreasing pattern during Mon1 and later increased during the PreM2. Phacus acuminatus, P. orbicularis, $P$. rotunda and $P$. skujae were observed in all the study seasons. They are generally abundant during the summer period $^{27,28}$. Trachelomonas cylindrica and T. naviculiformis were observed only during PreM2.

CCA was performed to determine the ecological relationship between 23 euglenoid species and 18 environmental variables. Table 3 provides the list of euglenoids with species code used in CCA.

In the present study, percentage of variance and eigen values of each study season (Figure 3) in axis 1 are higher than the axis 2. Similar observations are reported by Liu et $a .^{29}{ }^{29}$ Sharma et $a l .^{30}$. The effect of multiple sets of environmental variables on the variability of plankton (euglenoid) species is clearly evident from the tri-plot obtained by CCA method for the two separate study periods. The CCA drawn (Figure 3) between all the 
RESEARCH ARTICLES

Table 3. List of euglenoids from the Museum Lake for canonical correspondence analysis with species code

\begin{tabular}{|c|c|c|c|}
\hline Euglenoid species & $\begin{array}{l}\text { Species } \\
\text { code }\end{array}$ & Euglenoid species & $\begin{array}{c}\text { Species } \\
\text { code }\end{array}$ \\
\hline Euglena deses Ehrenberg & 1 & Phacus skujae Skvortzov & 13 \\
\hline Euglenaria clepsydroides B. Zakrys & 2 & Trachelomonas caudata (Ehrenberg) F. Stein & 14 \\
\hline Lepocinclis fusiformis (H. J. Carter) Lemmermann & 3 & Trachelomonas conica Playfair & 15 \\
\hline Lepocinclis horridus Pochmann & 4 & Trachelomonas conica var. richmondiae Playfair & 16 \\
\hline Lepocinclis ovum (Ehrenb.) Lemm. var. bütschlii Conr. & 5 & Trachelomonas cylindrica Ehrenberg & 17 \\
\hline Lepocinclis ovum var. gracilicauda Deflandre & 6 & Trachelomonas hispida (Perty) F. Stein & 18 \\
\hline Phacus acuminatus stokes & 7 & Trachelomonas naviculiformis Deflandre & 19 \\
\hline Phacus granum Drezepolski & 8 & Trachelomonas playfairii Deflandre & 20 \\
\hline Phacus orbicularis K. Hübner & 9 & Trachelomonas raciborskii Woloszynska & 21 \\
\hline Phacus longicauda var. rotunda (Pochmann) Huber-Pestalozzi & 10 & Trachelomonas superba Svirenko & 22 \\
\hline Phacus pleuronectus (O. F. Müller) Nitzsch ex Dujardin & 11 & Trachelomonas volvocina (Ehrenberg) Ehrenberg & 23 \\
\hline Phacus rotunda (Pochmann) Zakrys and M. Lukomska & 12 & & \\
\hline
\end{tabular}

Table 4. Average abundance during the study period (two years). The underlined leading species $(1,18,23)$ are further discussed and plotted separately in Figure 1 for seasonal variations

\begin{tabular}{|c|c|c|}
\hline & Euglenoid species & Cells/ml \\
\hline 1. & Euglena deses & $\underline{492}$ \\
\hline 2. & Euglenaria clepsydroides & 5 \\
\hline 3. & Lepocinclis fusiformis & 67 \\
\hline 4. & Lepocinclis horridus & 18 \\
\hline 5. & Lepocinclis ovum var.butschlii & 16 \\
\hline 6. & Lepocinclis ovum var.gracilicauda & 6 \\
\hline 7. & Phacus acuminatus & 30 \\
\hline 8. & Phacus granum & 7 \\
\hline 9. & Phacus orbicularis & 38 \\
\hline 10. & Phacus longicauda var.rotunda & 21 \\
\hline 11. & Phacus pleuronectus & 61 \\
\hline 12. & Phacus rotunda & 47 \\
\hline 13. & Phacus skujae & 79 \\
\hline 14. & Trachelomonas caudata & 59 \\
\hline 15. & Trachelomonas conica & 13 \\
\hline 16. & Trachelomonas conica var.richmonidae & 6 \\
\hline 17. & Trachelomonas cylindrica & 3 \\
\hline 18. & Trachelomonas hispida & $\underline{193}$ \\
\hline 19. & Trachelomonas naviculiformis & 2 \\
\hline 20. & Trachelomonas playfairii & 74 \\
\hline 21. & Trachelomonas raciborskii & 14 \\
\hline 22. & Trachelomonas superba & 31 \\
\hline 23. & Trachelomonas volvocina & $\underline{408}$ \\
\hline
\end{tabular}

environmental variables and euglenoid species. This obtained an Eigen value for axis $1(0.180)$ that explained $52.64 \%$ of correlation whereas, axis $2(0.113)$ that explained $33 \%$ of correlation between the studied variables and species. The arrow length in the CCA tri-plot shows a positive or negative correlation with one or more variable ${ }^{29-31}$. Figure 3 shows that the seasonal variation in cell number of the dominant species has a relationship with some of the hydrographical parameters like rainfall (-), conductivity $(+)$, phosphate $(+)$ and nitrate $(-)$ in the $\mathrm{Mu}-$ seum Lake.

In order to understand the nature of these relationships, it has to be established whether these are direct interactions, indirect causalities or just coincidences. Although

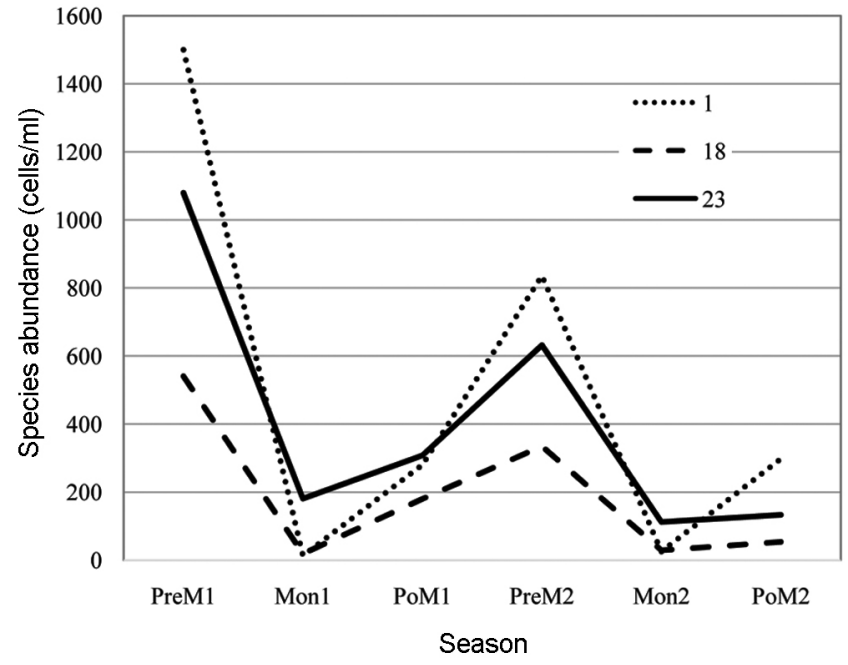

Figure 2. Seasonal diversity of the three leading euglenoid species in the Museum Lake for the two-year study period: $1=$ Euglena deses; 18 = Trachelomonas hispida; 23 = Trachelomonas volvocina .

the environmental parameters have been used as independent input variables, some of these variables are influenced by others.

The correlation between EC and rainfall that is represented in the CCA triplot is explained in Figure 4. Here, rainfall rate is taken as an independent variable for the Museum Lake. From the graph, there was a visible correlation between rainfall and electrical conductivity. As a result of rain, the cold rainwater will dilute (overturn) the water column and thus it acidifies the lake water.

In the case of the Museum Lake (that maintains its water level) it is likely that ions are transported via the lake bottom, mainly by carrying in bottom minerals like calcium and magnesium that contributes to the water harness. This explains that the water conducts an electric current better as the water contains more divalent ions such as calcium and magnesium shown by a low softwater ionic ratio (Figure 5). This means that rainfall did 


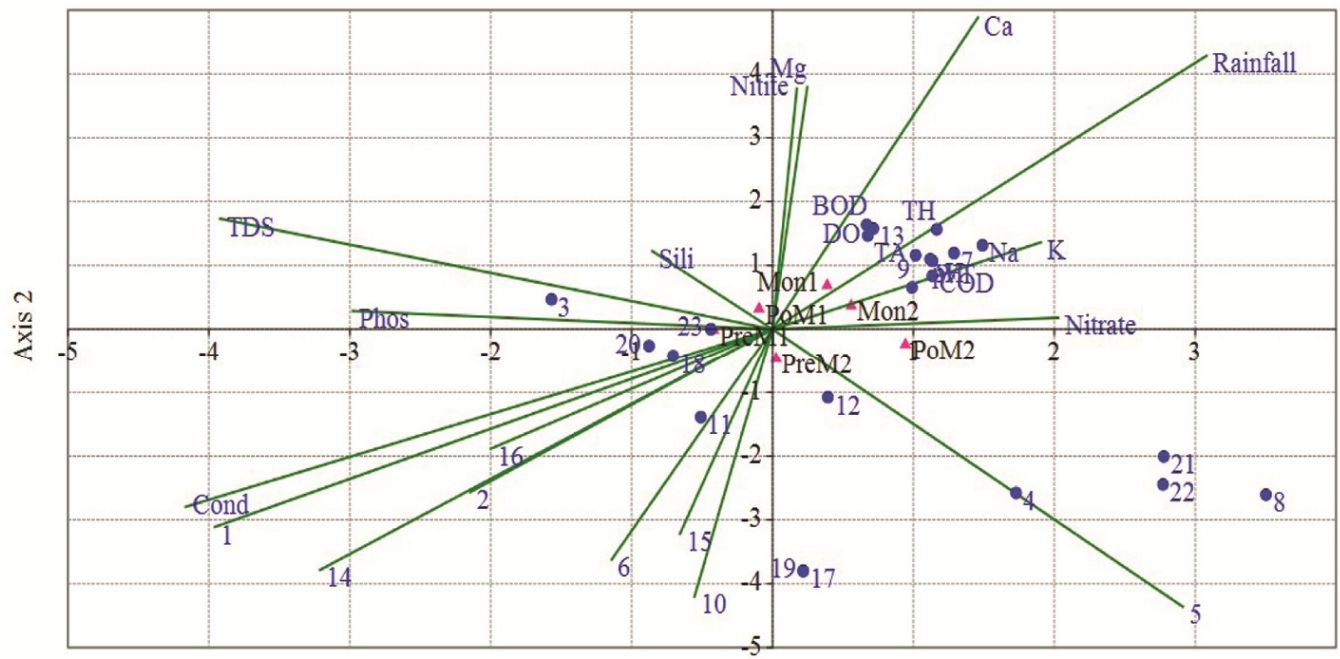

Axis 1

Figure 3. Canonical correspondence analysis (CCA) tri-plot showing the relation between euglenoid species (23) and environmental variables (18) in the Museum Lake, for the two-year study period. Dots represent the species (code numbers); arrow length indicates relative importance (correlation strength) towards those parameters; arrow direction indicates a positive or negative (opposite) relationship with each variables and species.

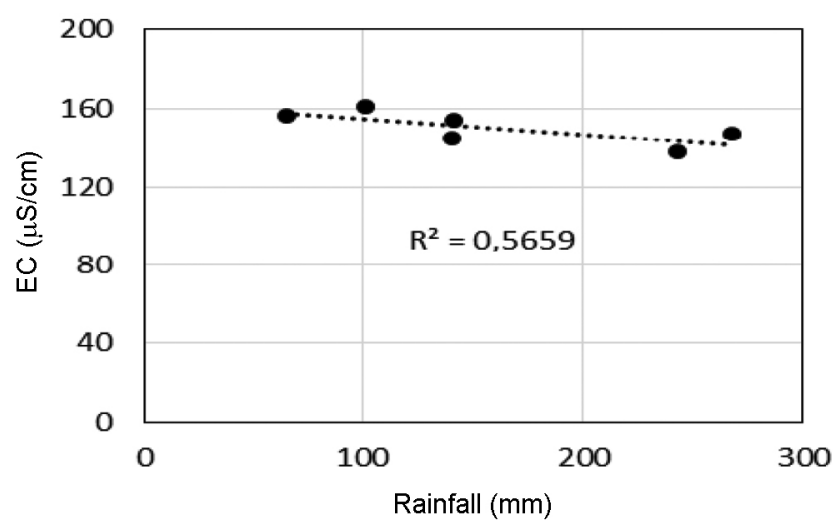

Figure 4. Electrical conductivity (EC) in the lake water versus amount of rainfall in the area.

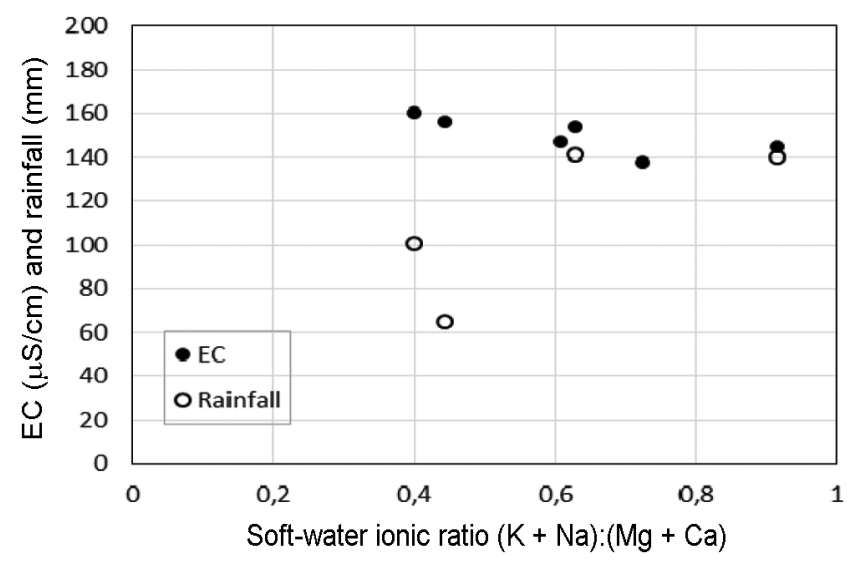

Figure 5. EC of the lake water versus soft-water ratio expressed as the sum of the major monovalent cations divided by the sum of the major divalent cations.

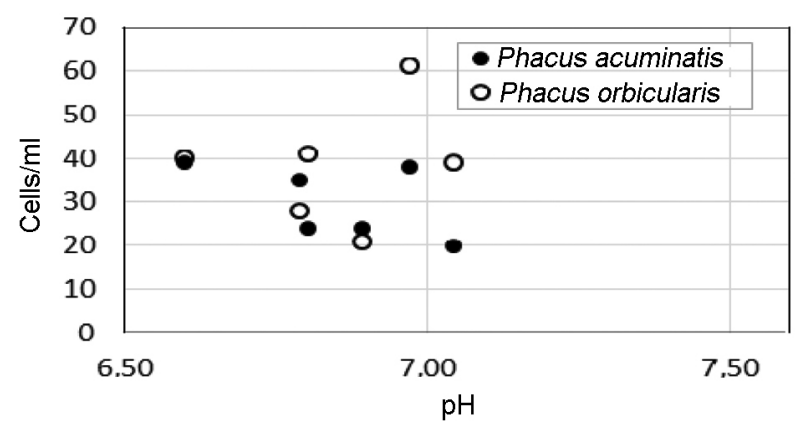

Figure 6. Relationships of two Phacus spp. with $\mathrm{pH}$ as indicated in the CCA plot.

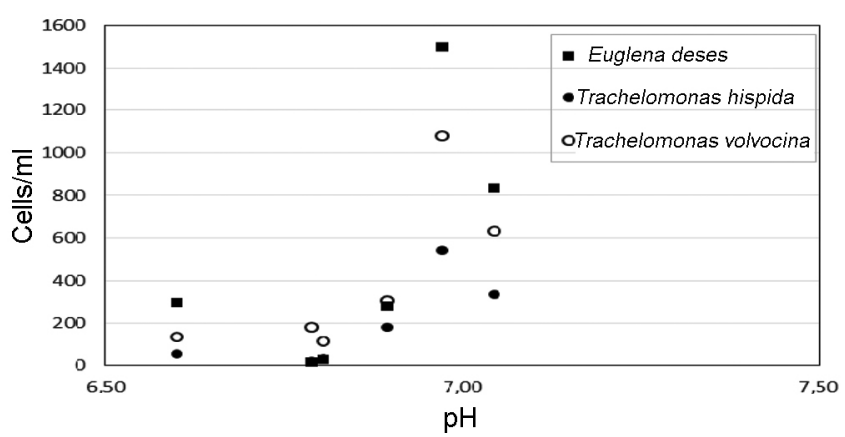

Figure 7. Cell number of dominant euglenoid species versus $\mathrm{pH}$ in the Museum Lake.

not help in softening the lake water. More rainfall is accompanied by more advection of groundwater and run-off from the surrounding land. It demonstrates how some 'independent' CCA input variables depend on each other. Cold rainwater may also overturn the water column.

CURRENT SCIENCE, VOL. 118, NO. 1, 10 JANUARY 2020 
RESEARCH ARTICLES
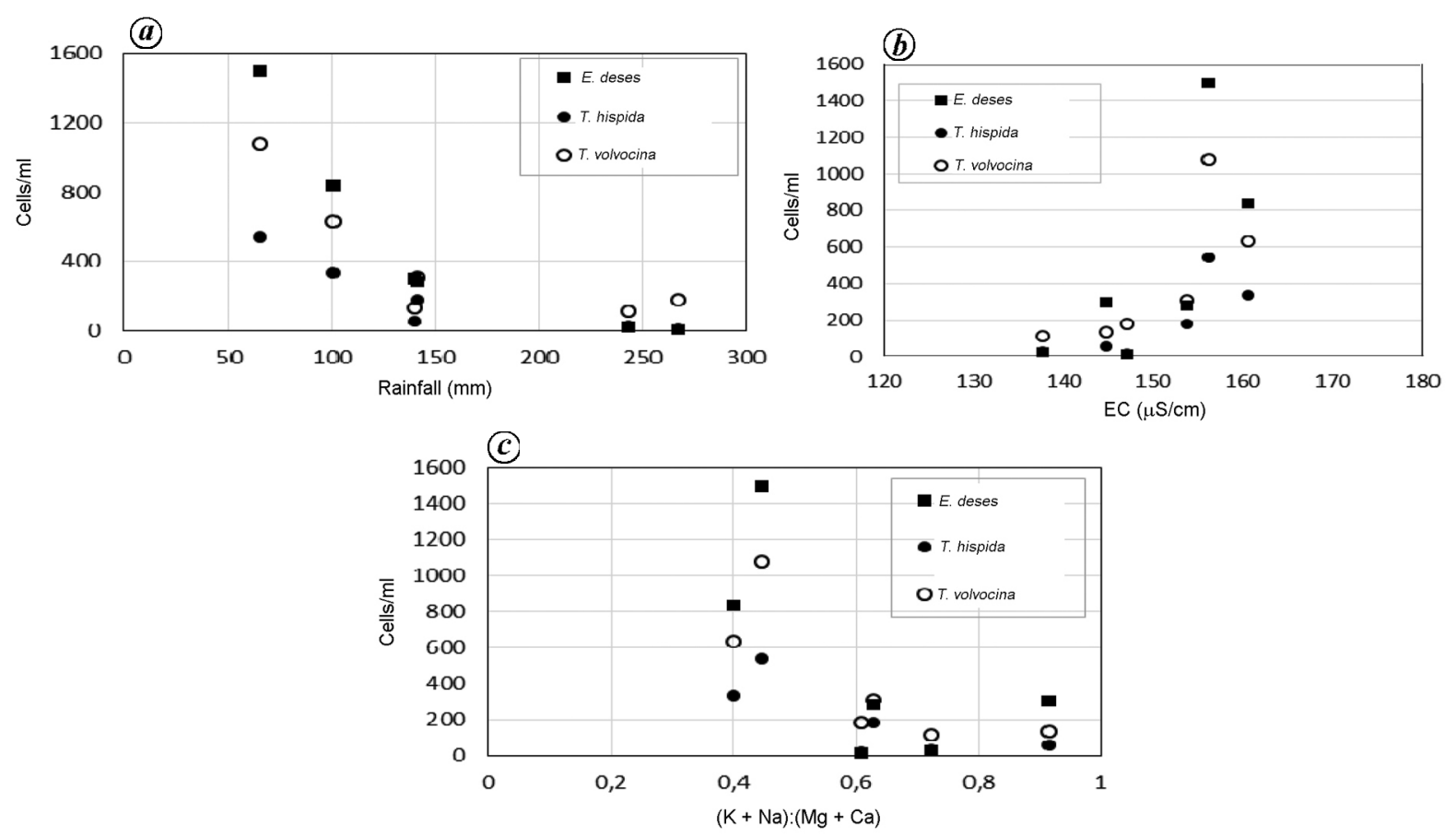

Figure 8. Trends of cell numbers of the three dominant euglenoids versus (a) rainfall; (b) EC, and (c) ratio of monovalent and divalent major ions.

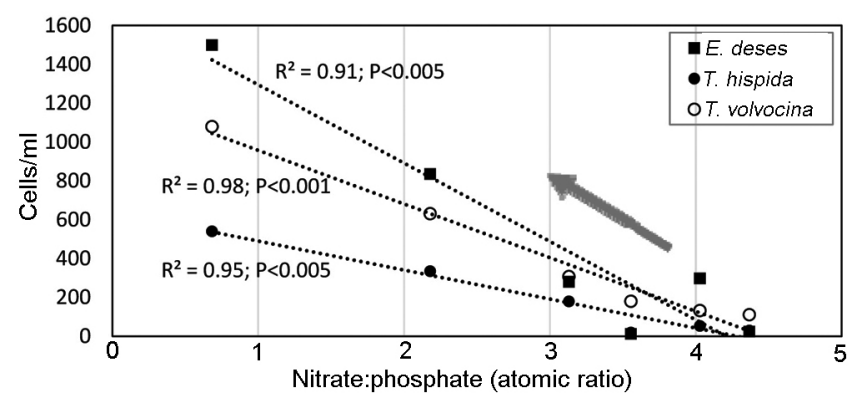

Figure 9. Cell number of dominant euglenoids versus inorganic $\mathrm{N}: \mathrm{P}$ ratio in the lake water. Arrow indicates that as biomass of the dominant species increase the nitrate concentration decreases.

Rainwater may slightly acidify the lake, but in the case of the Museum Lake there was no significant influence of rainfall or $\mathrm{EC}$ on $\mathrm{pH}$, which varied slightly between 6.5 and 7.6, viz. neutral to slightly acidic. The CCA tri-plot suggests that growth of both $P$. acuminatus and $P$. orbicularis is promoted by a higher $\mathrm{pH}$; however Figure 6 shows no significant effect.

From the CCA tri-plot (Figure 3 ) pH is pointing oppositely to species nos 1,18 and 23 which are dominant in the lake. This indicates that at lower $\mathrm{pH}$, E. deses, T. hispida and $T$. volvocina would show higher abundance. This is contradicted by directly plotting the specific cell numbers versus $\mathrm{pH}$ (Figure 7); cell density increased with $\mathrm{pH}$ or at high micro-algal densities $\mathrm{pH}$ increased as a result of $\mathrm{CO}_{2}$ uptake. Usually, at high $\mathrm{pH}$ (8.5-10), there will be a limitation of inorganic carbon in algal cells and increased photorespiration resulting in poor growth. Here the average $\mathrm{pH}$ is below 7.1.

A pH below 8.0 is considered as suitable for growth of euglenoids ${ }^{32,33}$. Venketeswarlu ${ }^{34}$ found that in River Moosi an average $\mathrm{pH}$ of 7.7 resulted in $5.1 \%$ increase in euglenoids, whereas at $\mathrm{pH} 8.2$ the euglenoid density decreased by $1.93 \%$.

E. deses, T. hispida and T. volvocina were the dominant euglenoids observed in samples of the Museum Lake. They showed increased growth during the premonsoon and post-monsoon seasons. All three showed a negative trend with rainfall (Figure $8 a$ ), conductivity (Figure $8 b$ ) and with $\left(\mathrm{K}^{+}+\mathrm{Na}^{+}\right)$relative to $\left(\mathrm{Mg}^{2+}+\right.$ $\mathrm{Ca}^{2+}$ ), i.e. the soft-water ratio (Figure $8 c$ ). This might be understood as 'dominant euglenoids are thriving in dry periods in relatively hard water'. The CCA tri-plot suggests that $P$. pleuronectus is negatively influenced by calcium (during PreM1, the $\mathrm{Ca}^{2+}$ concentration was $13.4 \mathrm{mg} / \mathrm{l}$ and cell number was 183 cells $/ \mathrm{ml}$ ). The CCA plot also suggests that $\mathrm{Ca}^{2+}$ suppressed the growth of Lepocinclis ovum var. gracilicauda (almost absent in this season); however, its low biomass may as well be due to unsuccessful competition with the dominant plankton species, not necessarily being a result of high $\mathrm{Ca}^{2+}$ concentration. Kim and $\mathrm{Boo}^{35}$ and Rahman et al. ${ }^{33}$ reported a bimodal pattern in the distribution of euglenoids in waterbodies, with maximum growth during pre-monsoon and post monsoon seasons.

T. volvocina was related to nitrate $(-)$ and to phosphate $(+)$ as indicated in the CCA tri-plot. An $X Y$ plot of the 


\section{RESEARCH ARTICLES}

abundance (cells $/ \mathrm{ml}$ ) of E. deses, T. volvocina and T. hispida versus nitrate concentration showed that the species had the highest cell numbers (pre-monsoon 2013) at the lowest $\mathrm{NO}_{3}^{-}$concentration $(1.73 \mathrm{mg} \mathrm{N} / 1)$, but nitrogen was never depleted. Nitrate/phosphate ratios were so low that phosphorus would never be the growth-limiting nutrient in the Museum Lake. Plots of cell abundances versus $\mathrm{N}$ : $\mathrm{P}$ ratio in the water show remarkably strong correlation (Figure 9).

If there was only a proportional decrease of phosphate with nitrate due to uptake by algae (atomic ratio $\mathrm{N}: \mathrm{P}=16: 1$ ), a slight decrease in phosphate would have been observed as the algal abundance decreased. However, exactly the opposite trend occurred; there was a considerable increase of inorganic phosphate parallel with algal cell numbers (Figure 10). As a consequence of nitrate uptake and phosphate input, $\mathrm{N}: \mathrm{P}$ ratio in the water decreased from 4.4 to 0.7 (pre-monsoon till monsoon). Successful growth of certain euglenoids is influenced by reduction of flow and accumulation of organic matter ${ }^{36}$. Growth of $T$. volvocina was promoted by higher concentrations of nitrate and phosphate released after decomposition of organic waste ${ }^{36-38}$.

Most of the euglenoids utilize inorganic nitrogen and phosphate in the presence of sunlight (photosynthesis). However, overnight they are mixotrophic, ingesting organic particles (phagocytosis) or absorbing dissolved organic compounds. There is no interaction (CCA) between the leading species nos 1,18 and 23 with either COD or BOD. So there is no justification that these species indicate 'organic pollution'. Moreover, BOD values lower than $10 \mathrm{mg} \mathrm{O}_{2} / 1$ are largely dark oxygen respiration rates of micro-algal populations, rather than oxygen demand of heterotrophic (aerobic) microbes degrading organic pollution. The fact that BOD and phosphate $\left(n=6 ; R^{2}=0.75\right.$; $P<0.05)$ were positively correlated does not imply that a high oxygen demand is related to phosphorus mineralization. It is more likely that an increase of phosphate in the water is a (combined) result of (a) input of $P$ from the surrounding area (although unlikely in the dry premonsoon of 2013) and (b) release of P from the lake sediments under anaerobic conditions in the pore water but evidence for this cannot be provided in the present study. It can be concluded that the relative abundance of the leading species is positively correlated with phosphate in the lake water.

From the above it is clear that 'independent' (abiotic) environmental parameters used in CCA often depend on other variables. Likewise, biotic parameters (cell numbers) are not only dependent on 'environmental parameters'; biota interact with each other either via food webs (e.g. algae eaten by herbivores) or via competition. In CCA, Lepocinclis horridus and L. ovum var. butschlii seem to be negatively influenced by dissolved silicate, but there is no logical explanation for the same. However, they were more or less co-developing with $P$. rotunda; there is no other explanation except that these three species are within the same niche. The number of Euglenaria clepsydroides from the Museum Lake was negatively influenced by rainfall, but also by Trachelomonas caudata (for unknown reasons). The CCA tri-plot shows fluctuations in cell number of Phacus granum, Trachelomonas cylindrica, T. naviculiformis, T. raciborskii and T. super$b a$ that were not influenced by any of the (measured) environmental variables. This may be due to selective grazing by 'herbivores ${ }^{39,40}$. The present results are consistent with those of Zafar ${ }^{5}$, Barone and Flores ${ }^{41}$, Kim and Boo $^{35,42}$. Euglenoids are cosmopolitans distributed over a wide range of environment especially in eutrophic waterbodies ${ }^{43}$. They respond to sudden changes in environmental conditions and therefore euglenoids are considered to be excellent bio-indicators. Because of their nutritional needs and their position at the base of the aquatic food web, phytoplankton indicators provide relatively unique information concerning ecosystem condition compared with commonly used animal indicators. However, information on unique indicators has to be clear in order to be useful. Three leading species were associated with a relatively dry season and hard phosphate-rich water, but in fact 'sunlight' may have also played a role. During pre-monsoon $\left(261 \mathrm{~W} / \mathrm{m}^{2}\right)$ solar radiation at the earth's surface is on average $20 \%$ higher than during monsoon $\left(216 \mathrm{~W} / \mathrm{m}^{2}\right)$ and post-monsoon $\left(222 \mathrm{~W} / \mathrm{m}^{2}\right)$. The

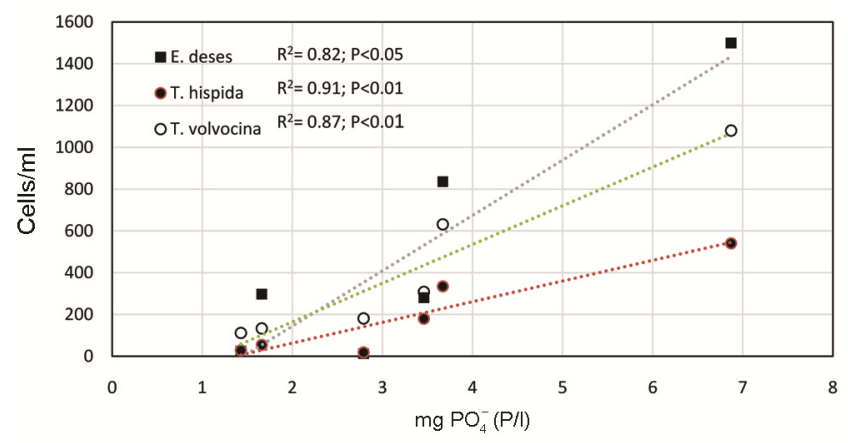

Figure 10. Plot of cell number of the three dominant euglenoids versus the inorganic phosphate concentration.

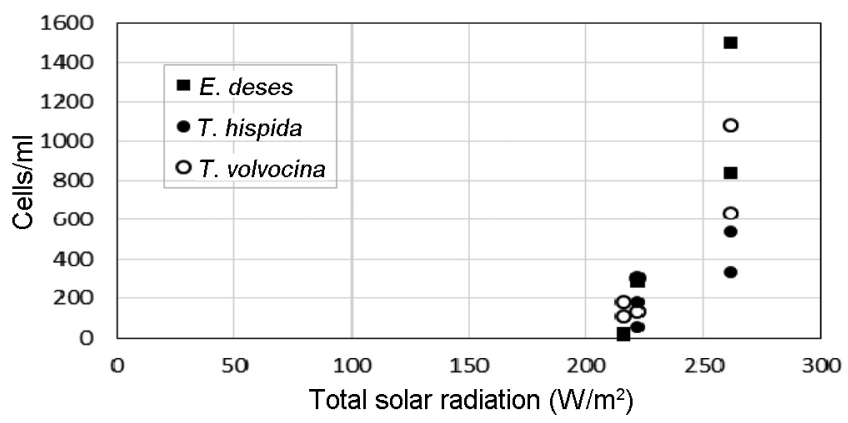

Figure 11. Cell number of the three dominant species versus 22-year average of seasonal (diurnal) solar radiation in Kerala (Source: NASA Atmospheric Science Data Center, USA). 
seasonal pattern of cell numbers as in Figure 2 followed the daily dosage of solar energy and it is clear from Figure 11 .

It is impossible to determine the effective watercolumn photosynthesis irradiance $(400-700 \mathrm{~nm})$ that these algae received (both during seasonal and diurnal cycle), since this irradiance depends on water transparency, light quality (absorption spectra), lake-water mixing (wind, thermal convection) and for (motile) euglenoids in particular, on the velocity of vertical phototaxis ${ }^{44}$. Considering this complexity, 'light' was not included as an independent parameter in the CCA. Still, periodic changes in solar radiation may interfere with the statistical analyses. In fact, a dry period with more sunlight may have favoured these dominant euglenoids, whereas inorganic phosphate was introduced in the system via external inputs or bottom processes. Phosphate was not a factor stimulating algal growth in this case, since it was available in excess. Here, 'phosphate' is considered to be a parameter indicating 'pollution/eutrophication'; E. deses, T. hispida and T. volvocina are considered to be 'guide' species providing useful warning signals of deteriorating conditions in disturbed ecosystems. Among the pollutiontolerant algae ${ }^{45}, E$. deses, P. pleuronectus and T. volvoci$n a$ also occur in the Museum Lake.

\section{Conclusion}

This study summarizes the diversity and seasonal distribution of 23 euglenoid algae and the most influential environmental variables in the Museum Lake. It is clear that some of the independent environmental input variables in the CCA in fact influence each other. Some relationships between 'abundance of algae' and 'environmental parameter' cannot be explained without a closer look at direct causality between a number of species and some abiotic factor which was not studied in the present research. Further analyses were done with three leading euglenoids that may serve as potential bio-indicators. Species showed marked seasonal variation having higher density during summer season and lower density during rainy season. E. deses, T. hispida and T. volvocina occur during dry pre-monsoon season, have an affinity for relatively hard but slightly acidic waters, and also have an affinity for phosphate-rich water, which is in agreement with the observations of Rahman et al. ${ }^{46}$. They respond to changes in water quality (eutrophic state) of the lake. This study further confirms the importance of phytoplankton in bio-monitoring and also the importance of the still unexplored euglenoids from Kerala.

1. Jahn, T. J., The euglenoid flagellates. Q. Rev. Biol., 1946, 21, 246-274.

2. Arguelles, E. D. L. R., Martinez-Goss, M. R. and Shin, W., Some noteworthy photosynthetic euglenophytes from Los Baños,
Laguna (Philippines) and its vicinity. Philipp. Sci., 2014, 51, $1-36$.

3. Ajayan, A. P. and Kumar, A. K. G., New geographical distribution of Euglenaria clepsydroides (Euglenophyceae) from India. Indian J. Trop. Biodivers., 2016, 24(1), 100-102.

4. Saxena, M. R., Freshwater Euglenineae from Hyderabad, India. J. Indian Bot. Soc., 1955, 34, 429-450.

5. Zafar, A. R., Two-year observation on the periodicity of Euglenineae in two fish breeding ponds. J. Indian Bot. Soc., 1959, 38, 491-540.

6. Munawar, M., Ecological studies of Euglenineae in certain polluted and unpolluted environments. Hydrobiologia, 1972, 39, 307-320.

7. Hosmani, S. P., A new species of the genus Phacus, Phacus bharatii sp. nov. Phykos, 1976, 15, 29-30.

8. Philipose, M. T., Contributions to our knowledge of Indian algae III. Euglenineae Part I. The genus Euglena Ehrenberg. Proc. Indian Acad. Sci. (Plant Sci.), 1982, 91, 551-599.

9. Philipose, M. T., Contributions to our knowledge of Indian algae III. Part 2. Proc. Indian Acad. Sci. (Plant Sci.), 1984, 93, 503552.

10. Philipose, M. T., Contributions to our knowledge of Indian algae3. Euglenineae Part 3. the genera Trachelomonas Ehrenberg and Strombomonas Deflandre. Proc. Plant Sci., 1988, 98, 317-394.

11. Shaji, C. and Patel, R. J., Contributions to euglenoids of Kerala, India. Phykos, 1991, 30, 109-114.

12. Sinha, S., Industrial Effluents and Organisms Inhabiting them, Pt. R.S. University Publications, Raipur, 2002, p. 174.

13. Ratha, S. K., Jena, M. and Adhikary, S. P., Euglenophytes from Orissa State, east coast of India. Algae, 2006, 21, 61-73.

14. Bhakta, S., Das, S. K. and Adhikary, S. P., Freshwater algae of Sikkim. J. Indian Bot. Soc., 2010, 89, 169-184.

15. Roy, A. S. and Pal, R., Freshwater euglenophytes from East Kolkata wetlands - a Ramsar site. Phytomorphology, 2016, 66, 113-121.

16. Pandey, U. C. and Pandey, D. C., Freshwater Euglenineae from Allahabad. J. Kanpur. Univ. Res., 1980, 1, 247-251.

17. Hosmani, S. P. and Bharati, S. G., Euglenineae of polluted and unpolluted water. Phykos, 1983, 22, 130-135.

18. Puttaiah, E. T. and Somashekar, R. K., Distribution of euglenoids in lakes of Mysore city. Phykos, 1987, 26, 39-46.

19. Kumawat, D. A. and Jawale, A. K., An ecological behaviour of euglenoids in a fish ponds: periodicity and abundance. J. Aquat. Biol., 2004, 19, 7-10.

20. Kumawat, D. A. and Patil, J., Euglenoids of polluted and unpolluted water from north Maharashtra. India. Ecoscan Spec. Issue 1, 2011,309-317.

21. Wołowski, K. and Hindak, F., Atlas of Euglenophytes, House of the Slovak Academy of Sciences VEDA/Publishing, Bratislava, Slovankia, 2005.

22. Ciugulea, I. and Triemer, R. E., A Color Atlas of Photosynthetic Euglenoids, Michigan State University Press, USA, 2010, p. 204.

23. Triemer, R. E. and Zakryś, B., Photosynthetic euglenoids. In Freshwater Algae of North America. Ecology and Classification (eds Wehr, J. D., Sheath, R. G. and Kociolek, R. P.), 2015, pp. 459-483.

24. Trivedi, M. K. and Goel, P. G., Chemical and Biological Methods for Pollution Studies, Environmental Publication, Karad, 1986, p. 247.

25. Wetzel, R. G. and Likens, G. E., Limnological Analyses, Springer, New York, 1991, 2nd edn, pp. 1-175.

26. APHA, Standard Methods for the Examination of Water and Wastewater, American Public Health Association, Washington, DC, 2005, 21 st edn.

27. Subakov-Simic, G., Floristical, Taxonomical and Ecological Investigation of Pigmented Euglenophyta of Serbia, Doctoral dissertation, Faculty of Biology, University of Belgrade, Serbia, 2006, p. 338. 
28. Predojević, D., Subakov-Simić, G., Kovačević, E., Papić, P., Ćuk, M. , Kljajić, Z. and Lazić, M., Diversity of the Euglenophyta division in the Zasavica River, Serbia. Bot. Serbia, 2015, 39, 23-29.

29. Liu, C., Liu, L. and Shen, H., Seasonal variations of phytoplankton community structure in relation to physico-chemical factors in Lake Baiyangdian, China. Proc. Environ. Sci., 2010, 2, 16221631 .

30. Sharma, R. C., Singh, N. and Chauhan, A., The influence of physico-chemical parameters on phytoplankton distribution in a head water stream of Garhwal Himalayas: a case study. Egypt. J. Aquat. Res., 2016, 42, 11-21.

31. Abrantes, N., Antunes, S. C., Pereira, M. J. and Goncalves, F., Seasonal succession of cladocerans and phytoplankton and their interactions in a shallow eutrophic lake (Lake Vela, Portugal). Acta Oecol., 2006, 29, 54-64.

32. Zakrys, B. and Walne, P. L., Floristic, taxonomic and phytogeographic studies of green Euglenophyta from the southeastern United States, with emphasis on new and rare species. Arch. Hydrobiol. Suppl., 1994, 102, 71-114.

33. Rahman, M. M., Jewel, M. A. S., Khan, S. and Haque, M. M., Study of euglenophytes bloom and its impact on fish growth in Bangladesh. Algae, 2007, 22, 185-192.

34. Venkateswarlu, V., An ecological study of the algae of the River Moosi, Hyderabad (India) with special reference to water pollution II. Factors influencing the distribution of algae. Hydrobiologia, 1969, 33, 352-363.

35. Kim, J. T. and Boo, S. M., Seasonal changes of the euglenoid species and the biomass in the Kumgang river. Algae, 1996, 11, 375 379 .

36. Santana, L. M., Moraes M. E. B., Silva, D. M. L. and Ferragut, C., Spatial and temporal variation of phytoplankton in a tropical eutrophic river. Braz. J. Biol., 2016, 76, 600-610.

37. Reynolds, C. S., Huszar, V., Kruk, C., Naselli-Flores, L. and Melo, S., Towards a functional classification of the freshwater phytoplankton. J. Plankton Res., 2002, 24, 417-428.

38. Rosowski, J. R., Photosynthetic euglenoids. In Freshwater Algae of North America: Ecology and Classification (eds Wehr, J. D. and Sheath, R. G.), Academic Press, San Diego, 2003, pp. 383416.

39. Reynolds, C. S., The response of phytoplankton communities to changing lake environments. Schweiz. Z. Hydrol., 1987, 49, 220235 .

40. Holzmann, R., Seasonal fluctuations in the diversity and compositional stability of phytoplankton communities in small lakes in upper Bavaria. Hydrobiologia, 1993, 249, 101-109.

41. Barone, R. and Flores, L. N., Phytoplankton dynamics in a shallow, hypertrophic reservoir (Lake Arancio. Sicily). Hydrobiologia, 1994, 289, 199-214.

42. Kim, J. T. and Boo, S. M., The relationships of green euglenoids to environmental variables in Jeonjucheon, Korea. Kor. J. Limnol., 2001, 34, 81-89.

43. Kim, J. T., Boo, S. M. and Zakryś, B., Floristic and taxonomic accounts of the genus Euglena (Euglenophyceae) from Korean fresh waters. Algae, 1998, 13, 173-197.

44. Jékely, G., Evolution of phototaxis. Rev. Philos. Trans. R. Soc. London, Ser. B, 2009, 364, 2795-2808.

45. Palmer, C. M., A composite rating of algae tolerating organic pollution. J. Phycol., 1969, 5, 78-82.

46. Rahman, M. M., Ghosh, J. K. and Islam, M. S., Relationships of euglenophytes bloom to environmental factors in the fish ponds at Rajshahi, Bangladesh. J. Agric. Veter. Sci., 2014, 7, 45-52.

ACKNOWLEDGEMENTS. We thank Dr Bożena Zakryś (University of Warsaw, Poland) for confirming the taxonomic identification of euglenoids. We also thank the Director, Museum and Zoo, Thiruvananthapuram and the Zoo Veterinarian as well as Dr R. Ravinesh (University of Kerala) for help during this study.

Received 19 November 2018; accepted 4 September 2019

doi: $10.18520 / \mathrm{cs} / \mathrm{v} 118 / \mathrm{i} 1 / 94-102$ 